\title{
SOCIO-ECONOMIC FACTORS AFFECTING POVERTY IN BALI PROVINCE, INDONESIA
}

\author{
Yoga I Made Sedana, Doctoral Candidate \\ Budhi Made Kembar Sri, Setiawina Nyoman Djinar, Professors \\ Saskara Ida Ayu Nyoman, Lecturer \\ Faculty of Economics and Business, University of Udayana, Denpasar, Bali, Indonesia \\ *E-mail: sedanayoga70@gmail.com
}

\begin{abstract}
The issue of poverty is still a strategic development issue carried out by the Bali Provincial Government. The poverty reduction efforts have been carried out by the regencies/cities of Bali Province with various development programs, but the number of poor people still shows that there is a level of poverty inequality between regencies/cities in Bali Province. This study aims to examine and analyze the influence of social and economic factors on poverty levels in the Bali Province, Indonesia. The social factors in question are population density, unemployment rate, education, and life expectancy. While several economic factors studied included investment, income distribution, and contribution of the agricultural sector. The data in this study are panel data covering socio-economic data and poverty levels in nine regencies/cities in Bali Province during the period 2007-2017. Data analysis was carried out with a quantitative approach using panel data multiple regression methods and equipped with descriptive analysis. The results of the study showed that education, investment, and the contribution of the agricultural sector has a negative effect on poverty levels. Population density, unemployment rate, life expectancy, and income distribution has a positive effect on poverty levels. Suggestions to policy makers, first, the regencies with low investment levels (Bangli, Karangasem, and Jembrana Regencies) to make innovative breakthrough efforts to attract investors to invest according to the potential of each region to support the sustainable development of Bali; and second, the consistency of pro-poor principles of social assistance spending policies.
\end{abstract}

\section{KEY WORDS}

Poverty level, population density, unemployment rate, education, life expectancy, investment, income distribution, contribution of agricultural sector.

Poverty alleviation has become a priority agenda in the policy framework in many countries as well as international organizations which is a commitment in the Millennium Development Goals (MDGs) which ended in 2015, and continues to the Sustainable Development Goals (SDGs) program. SDGs as a continuation agreement of the MDGs commitment consists of five elements, namely human, planet, welfare, peace and partnership, and to achieve the three noble goals of the nation's life in 2030, among them is to end poverty.

Sustainable development of a nation can be directed at three main things, namely increasing the availability and expansion of the distribution of basic necessities for the community, improving the welfare of the community (material well being), and increasing the ability of communities to access (expand choices) as well as economic activities and social activities in their lives (Todaro, 2011).

The issue of poverty is a strategic issue of development carried out by the Bali Provincial Government. The strategy implemented is in accordance with the mission of Realizing a Prosperous and Inner Birth of Bali is how the decline of the poor can continue to be improved and how the new poor will not occur again. The poverty alleviation efforts have been carried out by the Provincial Government of Bali with various development programs, but there is still an increase or decrease in the number of poor people in several districts, and the fact is that there are still poverty levels between regencies/cities in Bali. There is a causal relationship between economic and social aspects with community welfare (poverty) as a 
result of development. But from the reality, development in order to improve economic and social living standards also depends on the role of government (expenditure allocation policy).

Based on this background, the purpose of this study is to find out and analyze the influence of social and economic factors on poverty levels in the Province of Bali, Indonesia. The social factors in question are population density, unemployment rate, education, and life expectancy. While several economic factors studied included investment, income distribution, and contribution of the agricultural sector.

\section{THEORETICAL REVIEW}

Development is interpreted as a multidimensional process that includes a variety of fundamental changes to the social structure, attitudes of society, and national institutions while continuing to pursue accelerated economic growth, handling income inequality, and alleviating poverty (Todaro, 2011). Todaro (2011) emphasized that there are at least three basic components/core values to understand the real meaning of development, namely sustenance, self-esteem, and freedom.

Economic development according to Jhingan (2016) is not enough with economic conditions, but is closely related to "human wealth, social attitudes, political conditions, and historical settings". Jhingan (2016) further elaborated on several economic development requirements which include: (1) the process of growth of economic development must be based on the ability of the domestic economy; (2) economic development related to efforts to eliminate market imperfections that cause barriers to sectoral expansion and development; (3) structural change, namely transition from traditional farming communities to modern industrial economies that lead to the opening of employment opportunities and increasing labor productivity, capital stock, utilization of new resources, and technological improvements; (4) capital formation which is the main key to economic development; (5) appropriate investment criteria, not only determines the level of investment but also the composition of investment; (6) the socio-cultural insights of the community must change if they expect economic development to work; and (7) an administrative presence that is accountable, has integrity and is not corrupt is a situation and condition i am inevitable (sine qua non) in economic development.

Poverty is no longer understood to be limited to economic inability, but also the failure to fulfill basic rights and differences in treatment for a person or group of people, men and women, in living a dignified life (Dadang, 2007). Sen (1999) in the edition of Development as Freedom, poverty is expressed as lack of capability (capability deprivation) rather than just emphasizing low income. Capability to function is the most important thing to determine a person's poor status.

Chambers (1987), states that the core problem of poverty actually lies in what is called a deprivation trap. According to Chambers (1987), poverty is an integrated concept that has five dimensions, namely: (1) proper; (2) powerless; (3) state of emergency; (4) dependency; (5) isolation.

The Central Bureau of Statistics (BPS) measures poverty using the concept of the ability to fulfill basic needs (basic needs approach). With this approach, poverty is seen as an economic inability to meet basic food and non-food needs as measured by expenditure. With this approach, head-count index can be calculated, which is the percentage of poor people to the total population. The method used is calculating the Poverty Line, where the population whose value is fulfilling food and non-food expenditure under the poverty line is categorized as poor.

The measure of poverty according to Nurkse (1953) in Arsyad (2010) in a simple and commonly used manner can be divided into three terms, namely: (1) absolute poverty; (2) relative poverty; (3) cultural poverty. Khomsan et al. (2015), there are several ways to calculate poverty lines such as head count index, poverty gap index, poverty severity index, and so on. Determination of the exact size of poverty according to economists in Todaro 
(2011), must meet the principles: (1) anonymity; (2) independence of the population; (3) boredom; (4) distributional sensitivity.

The causes of poverty include economic and non-economic (social) factors which result in the inability to earn income in improving the quality of life in the community thereby reducing the level of welfare of a community.

At present population issues are the main issue of development, especially concerning population growth and the social-economic implications of development. According to Todaro (2011), very rapid population growth often leads to impoverishment. This opinion is reaffirmed by Todaro (2011), that the real problem is in the distribution of the population. Not the number of people causing problems, but the distribution of population or population density in a region cannot compensate for the availability of land and other resources. Empirical evidence at the household level has a very significant correlation and ensures that the negative consequences of rapid population growth have befallen almost all poor people.

According to Fields et al. (2007), there is a close relationship between poverty and minimum wages. Unemployment called open unemployment or the open unemployment rate is one indicator of the employment situation in a region or country. According to Kuncoro (2015), the condition of the working age population included in the unemployment group is measured by the open unemployment rate indicator, as a percentage of the number of unemployed workers. The TPT indicator is used as an ingredient in evaluating the success of reducing the number of poverty and economic development programs in Indonesia.

The level of education of a person increases the opportunity to get a better job and additional income. According to Simmons in Todaro (2011), education is a way to save themselves from poverty. Where with the higher education that is owned by the community, the greater the ability and opportunity to earn income and good work, so that it will be the furthest from existing poverty. Research conducted by Ezebuilo and Emmanuel (2014) found that higher education has the capacity to reduce poverty. There is a negative relationship between education and poverty, where the higher the education that is owned by the community, the smaller the poverty in the community will be. Those who have higher education can increase their income, so that economic conditions are above those with lower education.

The better the health of a community, the healthier and longer the productive age of a person, it is possible to have the capacity and opportunity to improve their welfare and avoid the threat of poverty. Studies revealed according to Todaro (2011) show that healthier people will get high wages and most of the health effects of increasing income are due to differences in productivity.

As explained earlier, that there are economic and non-economic (social) factors which are alleged to cause poverty. Wahyuni (2004) concluding that the two best policies for empowering the poor, especially in developing countries, i.e.: (1) increasing investment and credit markets for the poor who are seen as successful in increasing economic growth, and (2) financial stabilization, international market openness and size moderate government. This policy will provide benefits if supported by the existence of effective institutions, social and political structures, which enable the poor to be more involved in development and reduce inequality between the poor and the rich. The assertion that capital formation is an important factor in development to alleviate poverty is stated Jhingan (2016), and further stated that with capital formation, the market will be created broadly and help market imperfections that will cut the vicious circle of poverty.

Research by Suryadarma et al. (2005) entitled "A Reassessment of Quality and Its Role in Poverty Reduction in Indonesia", showing that in this study period there was a mixed pattern of inequality trends, decreasing during 1984 and 1990, increasing between 19901996, decreasing sharply in the year 1999 and increased again in 2002. The findings of this study are that the lowest inequality occurred in 1999 with a higher poverty rate than 1993. Furthermore, this study also proves the importance of reducing inequality as a way to increase the influence of economic growth on poverty reduction, because inequality affects poverty growth elasticity. At a high level of inequality, growth will have little influence in reducing poverty. 
Todaro (2011) states that more than two-thirds of people with extreme world poverty are involved in agricultural activities. And more than two-thirds of the poorest people in the world live in rural areas that mostly live from subsistence agriculture, where the most important thing for them is to survive. Increasing agricultural productivity will increase income in the agricultural sector and certainly will affect the welfare of farmers. This is in line with the results of Dewbre et al. (2011) that the growth of the agricultural sector will reduce the level of poverty in a region.

\section{FRAMEWORK AND HYPOTHESES}

Raising the issue of poverty does not only cover the fulfillment of basic needs from economic aspects, but also includes non-economic aspects such as social, cultural, environmental, political, and even institutional aspects. This study analyzes economic aspects which include investment, income distribution, and contribution of the agricultural sector, as well as social aspects which include population density, unemployment, education, and life expectancy. The concept of this study is the logical relationship between foundations and empirical studies that have been described in the literature review as show as Figure 1.

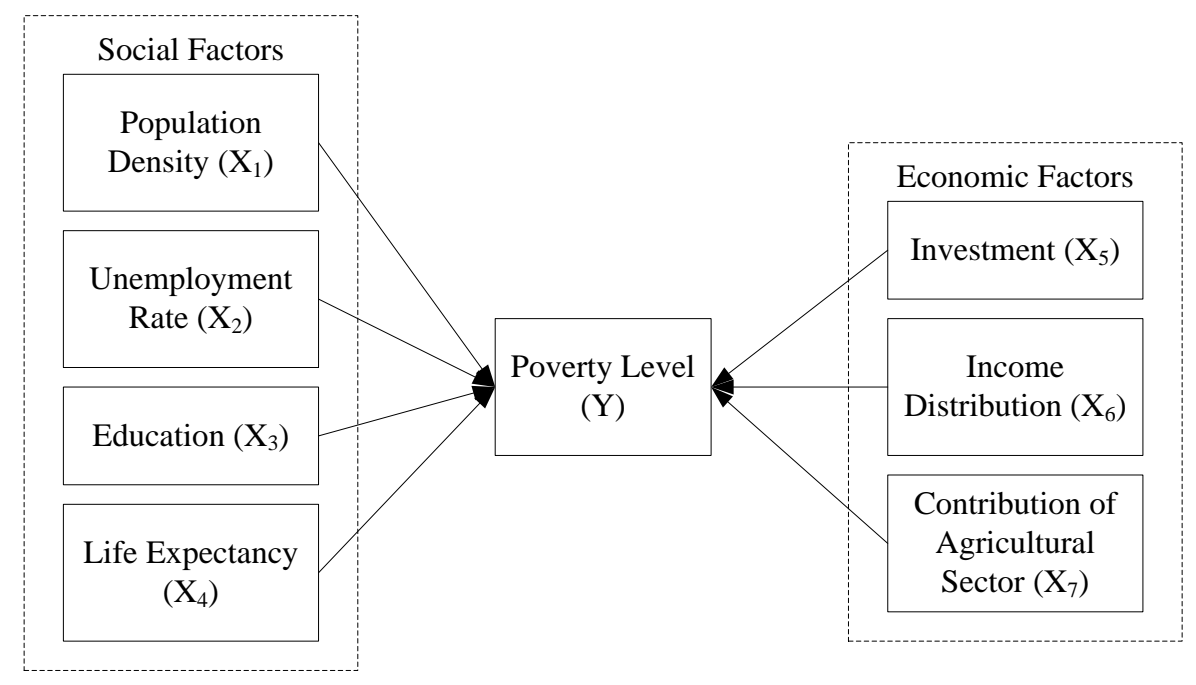

Figure 1 - Conceptual Framework

Based on the conceptual framework, two research hypotheses can be prepared:

- The population density and unemployment rate have a positive effect on poverty levels in Bali Province;

- Investment, income distribution, contribution of the agricultural sector, education, and life expectancy have a negative effect on poverty levels in Bali Province.

\section{METHODS OF RESEARCH}

This research will be carried out in the regencies/cities of Bali Province which have been implementing various poverty alleviation programs. Poverty alleviation programs have been implemented by each regencies/cities and province of Bali, but there are still phenomena of poverty inequality in 9 (nine) regencies/cities of Bali Province which are geographically located in one island unity, so that more analysis is needed further related to the poverty of regencies/cities in Bali Province. The data in this study are panel data, which is a combination of cross section and time series data, which consists of data on several socio-economic factors and poverty in nine regencies/cities in Bali Province during the period 2007-2017.

The data analysis technique in this study uses a quantitative approach with panel data regression. Panel data regression analysis will provide better results statistically because the 
incorporation of cross-site data and sequential time data will produce a greater degree of freedom, will provide more data, and can overcome the problem of variable omission (Sriyana, 2014).

In this study, the poverty model is assumed to be based on the theory and empirical causes of poverty contained in this study, and then a panel data regression model is formulated as follows:

$$
\text { Yit }=\beta 0+\beta 1 X 1 \text { it }+\beta 2 X 2 i t+\beta 3 X 3 i t+\beta 4 X 4 i t+\beta 5 X 5 i t+\beta 6 X 6 i t+\beta 7 X 7 i t+e i t
$$

Where:

$Y_{i t}=$ Poverty of nine regencies/cities in Bali Province in 2007-2017;

$X_{1 \text { it }}=$ Population density of nine regencies/cities in Bali Province in 2007-2017;

$\mathrm{X}_{\text {2it }}=$ Unemployment rate;

$\mathrm{X}_{3 \mathrm{it}}=$ Education;

$\mathrm{X}_{4 \mathrm{it}}=$ Life expectancy;

$\mathrm{X}_{5 \mathrm{it}}=$ Investment;

$\mathrm{X}_{6 i \mathrm{i}}=$ Income distribution;

$\mathrm{X}_{7 \mathrm{it}}=$ Contribution of agricultural sector;

$\beta_{0}=$ Constanta;

$\beta_{1-7}=$ Regression Coefficient;

$\mathrm{e}_{\text {it }}=$ Error Term (the estimation error rate) .

General panel data regression equation (Equation 1.) Above, will adapt the method of election results approach best estimates.

\section{RESULTS AND DISCUSSION}

The analysis of panel data regression results is done after getting the best model through testing the right model selection to use. The model selection test consists of two testing stages, namely: (1) the Chow Test to choose the common effect or fixed effect model; and (2) the Hausman Test to choose the random effect or fixed effect model. Before analysis of panel regression results on the selected model (Common Effect Model/CEM, Fixed Effect Model/FEM or Random Effect Model/REM), the selected model (CEM or FEM model) must meet the classical assumptions because the estimation of the two models is classic linear regression model with estimation method of ordinary least square (OLS) (Gujarati, 2007).

The initial stage of testing is to get a model approach with the best estimation between the common effect model or the fixed effect done by the Chow test. The model tested is a panel data regression model without entering moderating variables according to the model equation 1.

Selection of common effect or fixed effect model which is right to use by comparing the calculation results of $F_{\text {statistic }}$ and $F_{\text {table. }}$. Based on the Chow test on equation 1, which is $F_{\text {statistic }}$ getting 10,0894 while $F_{\text {table }}$ significant at $5 \%$ from dari numerator 8 and denumerator 83 obtained a value 2,02 , it can be concluded that the $F_{\text {statistic }}$ more than $F_{\text {table }}(10.0894>2.02)$, so the exact model used between common effect and fixed effect is Fixed Effect Model (FEM). The same results are obtained by testing using the Eviews version 10 application to determine which CEM or FEM model can be used, such as Table 1 below.

Table 1 - Test Result between Common Effect and Fixed Effect Model for Panel Regression Equation Model

\begin{tabular}{cccc}
\hline Effects Test & Statistic & d.f. & Prob. \\
\hline Cross-section F & 9.812639 & $(8,83)$ & 0.0000 \\
Cross-section Chi-square & 65.901470 & 8 & 0.0000 \\
\hline
\end{tabular}

Based on the output of Table 1, the Prob value is obtained. Cross-Section Chi-Square $(0,000)$ is significant with Sig. 0.000 , the right model is used between the common effect 
model and the fixed effect is a Fixed Effect Model (FEM). The results with this test are the same as the results using the previous Chow Test.

The next step after the Chow test with the selected fixed effect model is that the test determines the model that is more accurately used between the fixed effect (FEM) or random effect (REM) model. Testing the selection of the best estimation model between the two models is done by the Hausman Test. Determination of the selected model is seen based on the prob value obtained from the results of the test of the hausman test. The test results obtained with the help of the Eviews application version 10 are shown in Table 2 below.

Table 2 - Testing Results between Random Effect and Fixed Effect Models for Panel Regression Equation Models

\begin{tabular}{cccc}
\hline Test Summary & Chi-Sq. Statistic & Chi-Sq. d.f. & Prob. \\
\hline Cross-section random & 63.895437 & 7 & 0.0000 \\
\hline
\end{tabular}

Based on the results of the Hausman Test in Table 2 above, the Prob value is obtained. $(0,000)$ less than 0.05 , then the hypothesis $\mathrm{HO}$ is rejected. Thus the right model used between fixed effect and random effect is a Fixed Effect Model (FEM).

The chosen FEM method is also called the Least-Squares Dummy Variable (LSDV) regression model where intercepts vary between regencies/cities (nine regencies/cities) and each intercept does not vary over time (time invariant). It can be said that the chosen FEM model is assumed that the slope coefficient of the regressor does not vary among regencies/cities and between times. Because FEM is based on a classic linear regression model that uses OLS methods, the model must fulfill the classic assumption in order to produce an unbiased linear estimator and have a minimum variant (Best Linear Unbiased Estimator/BLUE) according to the Gauss-Markov theorem (Ghozali and Ratmono, 2017).

This study analyzes panel data with the Pooled Least Square (PLS) technique so that only Multicollinearity and Heteroscedasticity tests are needed. The model regression results have been freed from multicierity testing, with the correlation value between independent variables below 0.9. In multicollinearity testing, the provisions of the model containing multicollinearity according to Hair et al. (2014), if the correlation value between all the independent variables tested is more than 0.9 to perfect multicollinearity with a value of 1.0 . Furthermore, using the help of the Eviews program version 10, the resulting regression results are results that are free of heteroscedasticity.

Panel data regression test results on the equation model (1) shown in Table 3 with the poverty panel regression model in Bali Province obtained:

$$
\begin{aligned}
& Y_{i t}=\beta_{0}+\beta_{1 .} X_{1 i t}+\beta_{2 .} X_{2 i t}+\beta_{3 .} X_{3 i t}+\beta_{4 .} X_{4 i t}+\beta_{5 .} X_{5 i t}+\beta_{6} . X_{6 i t}+\beta_{7 .} X_{7 i t}+e_{i t} \\
& Y_{i t}=6,3199+0,0008 X_{1}+0,1025 X_{2}-0,7944 X_{3}+0,0635 X_{4}-0,0639 X_{5}+0,0768 X_{6}-0,0252 X_{7}
\end{aligned}
$$

Where: $Y_{i t}=$ Poverty level; $X_{1}=$ Population Density; $X_{2}=$ Unemployment Rate; $X_{3}=$ Education; $X_{4}=$ Life Expectancy; $X_{5}=$ Investment; $X_{6}=$ Income Distribution; $\mathrm{X}_{7}=$ Contribution of Agricultural Sector.

Pointing to Table 3 above, the output of the eViews application shows seven independent variables used, namely the investment variable (PMTDB), income distribution (INCD), agricultural sector contribution (AGRIC), population density (PDD), unemployment rate (TPT), education (RLS), and life expectancy $(\mathrm{AHH})$. The results of calculation of the $F$ test or simultaneous test which is also a model validity test, there are simultaneous effects of investment variables, income distribution, agricultural sector contribution, population density, unemployment rate, education, and life expectancy on poverty level variables. The value of $F$ shows a number of 43.42 , which is much greater than the value of Ftable at a free degree of 7: 91 with a significant level of 5 percent of 2.11. The significance of the effect simultaneously of the independent variables on the dependent variable is also indicated by the value of the Prob. (F-statistic) of 0,000 which is smaller than the real level of 5 percent. 
Based on the output of the processing, the R2 determinant coefficient of 0.8869 shows the ability of independent variables (free) to explain the dependent variable (bound) of 88.69 percent. This means that 88.69 percent of the poverty level variables that occur can be explained by using investment variables, income distribution, agricultural sector contribution, population density, unemployment rate, education, and life expectancy, while the remaining 11.31 percent can be explained by other variables in outside the model.

Table 3 - Results of Test of Poverty Panel Panel Data Regulations in Bali Province 2007-2017

\begin{tabular}{llll}
\hline \hline Variable & Coefficient & t-Statistic & Prob. \\
\hline C & 6.3199 & 0.8409 & 0.4028 \\
PDD $\left(X_{1}\right)$ & 0.0008 & 3.6076 & 0.0005 \\
TPT $\left(X_{2}\right)$ & 0.1025 & 1.0376 & 0.3025 \\
RLS $\left(X_{3}\right)$ & -0.7944 & -2.5994 & 0.0111 \\
AHH $\left(X_{4}\right)$ & 0.0635 & 0.5891 & 0.5574 \\
PMTDB $\left(X_{5}\right)$ & -0.0639 & -3.1220 & 0.0025 \\
INCD $\left(X_{6}\right)$ & 0.0768 & 1.9747 & 0.0516 \\
AGRIC $\left(X_{7}\right)$ & -0.0252 & -0.8014 & 0.4252 \\
Fixed Effects (Cross) & & & \\
_JBR--C & 1.6407 & & \\
-TBN--C & 0.7732 & & \\
-BDG--C & -1.2482 & & \\
-GNY--C & 0.4285 & & \\
-KLK--C & 1.7756 & & \\
BGL--C & 0.5618 & & \\
-KRG--C & -0.3125 & & \\
-BUL--C & 0.8087 & S.E. of regression & \\
DPS--C & -4.4278 & F-statistic & \\
R-squared & 0.8869 & & \\
Adjusted R-squared & 0.8665 & & 0.7003 \\
Sum squared resid & 40.7101 & & 0.4243 \\
\hline
\end{tabular}

Equation model 3 and output Table 3 for partial test analysis (two-way t test) shows that with the value of 91 independent degrees at the critical point $-1,986$ and 1,986, the variables that significantly influence the poverty level are the variable density population (X1), education (X3), and investment (X5). The results of the probability value (Prob.) Based on processed data with eViews also show the same results, where the three poverty determinant variables are significant with the Prob value. smaller than $5 \%$.

The partial test results concluded: 1) education, investment, and the contribution of the agricultural sector negatively affected the poverty level. The negative effect of education is significant with a coefficient of 0.7944 ; significant investment with a coefficient of 0.0639 ; and the contribution of the agricultural sector is not significant with a coefficient of 0.0252 ; and 2) population density, unemployment rate, life expectancy, and income distribution have a positive effect on poverty levels. Positive influence of significant population density with a coefficient of 0,0008 , the unemployment rate is not significant with a coefficient of 0.0125 , life expectancy is not significant with a coefficient of 0.0635 , and income distribution is not significant with a coefficient of 0.0768 . Thus, based on the direction of the relationship, the poverty determinant variables are statistically proven, except for income distribution and life expectancy which have no negative effect on poverty levels, but are not significant.

Based on the constant fixed effect (cross) coefficient of the regression model mentioned above, the largest fixed effect (cross) value is owned by Klungkung Regency at 8.0954 and the smallest one is owned by Denpasar City with a coefficient of 1.8921. The difference in the value of fixed effect (cross) shows how much the difference between one region and another region. Each region has its own characteristics reflected in other variables outside the independent variables in the model. 


\section{DISCUSSION OF RESULTS}

As the results of the panel data linear regression analysis described earlier, the results of the analysis revealed and proved that together (simultaneously) the variable population density, unemployment, education, life expectancy, investment, income distribution, and contribution of the agricultural sector had a significant effect the level of poverty in the Province of Bali. This shows that all independent variables in the study together play a role in influencing the level of poverty in the province of Bali. According to the results of the analysis, the role of the variable population density, unemployment, education, life expectancy, investment, income distribution, and contribution of the agricultural sector can explain the dependent variable poverty rate of 88.7 percent, while the remaining 11.3 percent is explained by other variables outside the unexamined model or other variables not included in the research model.

The value of the intercept produced by assuming the heterogeneity of the poverty levels of regencies/cities in Bali Province shows that the poverty rate of Denpasar City is the lowest compared to other districts to rate all the same independent variables. During the 2007-2017 study period the poverty rates in Denpasar City ranged from the lowest 1.52 percent and the highest 2.39 percent, with an average poverty rate of 2.1 percent. The regency which shows the highest poverty level for the value level of all the same independent variables is Klungkung Regency. In the intervals of the study period, the poverty rate in Karangasem Regency ranged from 5.23 percent to the highest reaching 9.14 percent, with an average poverty rate of 6.73 percent. Furthermore, the partial analysis of the influence of the independent variables on the level of poverty obtained the following results.

Population density variables have a positive effect on poverty levels or there is a positive relationship between population density and poverty level. This means that population density has an effect on increasing poverty levels in Bali Province. The highest population density in 2017 is in Denpasar City followed by Badung Regency and Gianyar Regency, and the lowest density is in Jembrana Regency. Areas with high population densities such as Denpasar City and Badung Regency have low poverty rates of 2.06 percent and 2.27 percent far below the other districts which range from 4.92 percent to 6.55 percent. Population density in both regions is undeniable as a result of the success of development and tourism development, which attract population migration, both because of better infrastructure infrastructure facilities, the potential for employment opportunities that promise jobs, more complete health facilities, and many choices access to education.

According to Guzman (2005), population density in an area caused by population migration to urban areas will have a positive impact on stimulating economic growth and encouraging poverty reduction in developing countries, insofar as the income of some emigrants is used to increase education and new investment. The issue of overcrowding that exceeds the existing environmental capacity and does not contribute to quality economic growth will lead to socio-economic problems that widen income inequality among community groups and decrease the quality of life of the community.

Variable unemployment rate has a positive effect on poverty levels or there is a positive relationship between unemployment and poverty levels. These results are similar to those of Osinubi (2005) who also found a unidirectional relationship between unemployment rates and poverty rates in Nigeria. In his research, concluded that the unemployment rate did not significantly influence the poverty level. This happens to see the fact that unemployed people in Nigeria are involved in various types of irregular work and make many workers richer and improve their quality of life. In many cases, some unemployed workers in Nigeria depend on their relatives who are not poor to survive, and get them out of the poverty trap.

Educational variables have a negative effect on poverty levels or there is a negative relationship between education and poverty levels. This means that the increase in education has a significant effect on reducing poverty in Bali Province.

The findings of this study in accordance with the results of previous studies which suggested the influence of education on poverty such as research conducted by Niazi and Khan (2008) found the importance of education to reduce multidimensional poverty. 
Similarly, the results of Aref's (2011) study found that there was a contribution of education to poverty reduction. Education helps alleviate poverty with its impact on labor productivity (Flor et al., 2006 in Aref, 2011). Furthermore it was stated that the important role of education in reducing poverty could not stand alone, the solution to rural poverty through multi-disciplinary fields that included economic, social, political and institutional factors. Research on the effect of the high and low levels of education on poverty was also revealed by Ezebuilo and Emmanuel (2014) who found that higher education has the capacity to reduce poverty.

Life expectancy variables do not negatively affect poverty levels or in other words, there is a positive relationship between life expectancy and poverty levels. The results of this study found a positive correlation between life expectancy and poverty levels in the Province of Bali, but the effect was not significant. This unidirectional but not significant relationship is different from the results of a study conducted by Geronimus et al. (2001) which found that there is a very strong relationship between life expectancy and the level of poverty in an area. His research found an inverse relationship between life expectancy and poverty levels. The higher life expectancy affects the decline in poverty. This happens because the degree of good health and old age that is still productive is still available in the study area.

Investment variables have a negative effect on poverty levels or there is a negative relationship between investment and poverty levels. This means that the increase in investment significantly decreases the percentage of poor people.

Overall in the period of the study year, the contribution of investment of regencies/cities tended to increase slowly and the percentage of poor people also declined. Thus, the contribution of physical investment (formation of capital accumulation) has a negative influence on the level of poverty. Increasing investment will reduce the percentage of poor people. This is in line with the results of research that supports the hypothesis that investment has a positive effect on poverty levels in Bali Province. This finding is in line with the research conducted by Fan et al. (2004) entitled The Importance of Public Investment for Reducing Rural Poverty In Middle-Income Countries: The Case Of Thailand, which found investment in agriculture, irrigation, rural areas, and infrastructure (including roads and electricity) had an impact on reducing rural poverty.

More specifically the results of a study conducted by Granados (2015) titled Does Transportation Infrastructure Reduce Poverty? Evidence from the Free Federal Trunk Highway System in Mexico states that investments aimed at road infrastructure lead to poverty reduction and have a greater impact during periods of economic contraction. Further found on average for each additional kilometer of the highway $(\mathrm{km} / 100 \mathrm{~km} 2)$, poverty was reduced by 0.4 percentage points. Then Eseyin et al. (2016) with his research entitled Investment in Agricultural Sector: Implication for Poverty Reduction in Nigeria (1985-2012) which identified various investment options in the agricultural sector and their implications for poverty reduction in Nigeria found productivity in the agricultural sector with the accumulation of physical capital in the form of facilities significant infrastructure in reducing poverty in the current year.

The income distribution variable does not negatively affect the poverty level or there is a positive relationship between the distribution of income and the level of poverty. This means that the increase in the percentage of income distribution for the $40 \%$ of the lower groups does not affect the decline in poverty rates in Bali Province, but it is not significant.

The per capita income of the lower community groups also has an impact on increasing their income mastery which will narrow the gap between lower class groups, moderate community groups, and high community groups, so that the distribution of income is evenly proportional should reduce the poverty level of the lower population.

According to Fosu (2010), the model for estimating the relationship of growth-povertyinequality, reveals that the lower the level of income, the more likely it will fall below the basic needs and make the individual fall into poverty. Conversely increasing income, the greater the possibility of the ability to meet basic needs and lift individuals from the trap of poverty.

Increased income that leads to lower inequality or inequality will reduce the poverty level of the community. This turned out to be less in line with the findings of this study, where the results of this study revealed a positive relationship between the distribution of income 
and the level of poverty. That is, an increase in the income distribution of the group of 40 percent below influences the increase in poverty levels.

The variable contribution of the agricultural sector has a negative effect on the level of poverty or there is a negative relationship between the contributions of the agricultural sector to the level of poverty. This means that the increase in the contribution of the agricultural sector influences the decline in the level of poverty in the Province of Bali, but the effect is not significant.

The results of the descriptive analysis as outlined in Chapter $\mathrm{V}$, show that throughout the period 2007-2017, there was a decline in the contribution of the agricultural sector in the formation of GDP at both the provincial and regencies/cities levels, with increasing GRDP growth. The findings of this dissertation study are different from those of Ligon (2008), Cervantes and Dewbre (2010), and Priyarsono (2011). Ligon found that agricultural growth for the poorest 10 percent of the group was substantially more important than the growth of the non-agricultural sector. Cervantes and Dewbre found that in reducing poverty, the role of agriculture is consistently greater than the contribution of the agricultural sector itself to GDP. And Priyarsono's research results also reveal the important role of the agricultural sector in overcoming poverty.

\section{CONCLUSION}

This study aims to examine and analyze the influence of socio-economic factors on poverty levels in Bali Province. Based on the results of the descriptive analysis and discussion that has been described, it can be concluded that education, investment, and the contribution of the agricultural sector have a negative effect on the level of poverty in Bali Province. Education, investment, and the contribution of the agricultural sector show an inverse relationship, so that the increase in investment education and the contribution of the agricultural sector will reduce the level of poverty in the Province of Bali.

While population density, unemployment rate, life expectancy, and income distribution have a positive effect on poverty levels in Bali Province. This means that population density, unemployment rate, life expectancy, and income distribution show a unidirectional relationship, so that increasing population density, unemployment rate, life expectancy, and income distribution will increase the poverty rate in Bali Province.

Based on the analysis, discussion, and conclusions described earlier, to improve the welfare of the people in Bali, especially to reduce poverty levels, it can be suggested to the Bali Provincial Government to encourage low-investment districts (Bangli, Karangasem, and Jembrana Regencies) to make breakthrough efforts innovative attract investors to invest their capital in accordance with the potential of each region to support the sustainable development of Bali. Development programs implemented to focus on inclusive economic growth based on equity (inclusive economic growth based on equity). Physical infrastructure investment opens access to remote rural areas reaching the lowest income groups of the community economy.

\section{REFERENCES}

1. Aref, Abrisham. (2011), "Perceived Impact of Education on Poverty Reduction in Rural Areas of Iran", Life Science Journal, Iran.

2. Arsyad, L. (2010), Ekonomi Pembangunan, Yogyakarta: UPP STIM YKPM.

3. Cervantes-Godoy, D. and Joe Dewbre. (2010), "Economic Importance of Agricultural for Sustainable Development and Poverty Reduction: finding from a case of Indonesia", Global Forum on Agriculture, 15-17 November 2010.

4. Chambers, R. (1987), "Sustainable Rural Livelihoods: A Strategy for People, Environment and Development", overview paper for only One Earth Conference on Sustainable Development organized by the International Institute for Environment and Development, April 1987.

5. Dadang, Solihin. (2007), Economic Development: Overview Indonesia Masa Krisis 1998. 
Jakarta: Artifa Duta Prakarsa.

6. Dewbre, J., D. Cervantes-Godoy and S. Sorescu. (2011), "Agricultural Progress and Poverty Reduction: Synthesis Report", OECD Food, Agriculture and Fisheries Working Papers, No. 49, OECD Publishing.

7. Eseyin, Oluwasegun. Toluyemi, Taiwo S. and Oni, Opeyemi Olusegun. (2016), Investment in Agricultural Sector: Implication for Poverty Reduction in Nigeria, American Journal of Business and Society, Vol. 1 No. 3 pp. 118-128.

8. Ezebuilo R, Ukwueze and Emmanuel O, Nwosu. (2014), "Does Higher Education Reduce Poverty Among Youths In Nigeria?", Journal Asian Economic and Financial Review, 2014, 4(1):1-19.

9. Fan, Shenggen. Jitsuchon, Somchai. and Methakunnavut. (2004), "The Importance Of Public Investment For Reducing Rural Poverty In Middle-Income Countries: The Case Of Thailand", DSGD Discussion Paper No. 7., International Food Policy Research Institute, Washington, USA.

10. Fields, Gary S., Baran Han and Ravi Kanbur. (2007), "Poverty Effects of the Minimum Wage: The Role of Household Employment Composition", Paper on Annual Convention of the Society of Labor Economics, Chicago, May 2007. NY: Cornell University Ithaca.

11. Fosu, Augustin Kwasi. (2010), "The Effect of Income Distribution on The Ability of Growth to Reduce Poverty: Evidence from Rural and Urban African Economies", American Journal of Economics and Sociologi, Inc., Vol. 69. No. 3. pp. 1034-1053.

12. Geronimus, Arline T. John Bound. Timothy A. Waidmann. Cynthia G. and Colenand Dianne Steffick. (2001), "Inequality in Life Expectancy, Functional Status, and Active Life Expectancy acrossSelected Black and White Populations in the United States", Demography, Vol. 38, No. 2 pp. 227-251.

13. Granados, Nayeli Noyolitzin Salgado. (2015), "Does Transportation Infrastructure Reduce Poverty? Evidence from the Free Federal Trunk Highway System in Mexico", Master in Economic Development and Growth, School of Economic and Management, Lund University.

14. Gujarati, Damodar N. (2007), Basic of Econometry,Third Edition, Jakarta: Penerbit Erlangga.

15. Guzman, Pilar Martin. (2005), Population and Poverty, Universita degli Studi di Roma La Sapienza - JSTOR.

16. Jhingan, M.L. (2016), Economic Development and Planning, Jakarta: Rajawali Pers.

17. Kuncoro, Mudrajat. (2015), Mudah Memahami dan Menganalisis: Indikator Ekonomi, Yogyakarta: UPP STIM YKPN.

18. Ligon, E. and E. Sadoulet. (2008), "Estimating the Effects of Aggregate Agricultural Growth on the Distribution of Expenditures", Background Paper for the World Development Report 2008, World Bank.

19. Niazi, Muh. Imran, Khan, Atta Ullah. (2008), "The Impact of Education on Multidimensional Poverty across The Regions in Punjab", Journal of Elementary Education, Vol. 21 No. 1 pp. 77-89.

20. Osinubi, Tokunbo Simbowale. (2005), "Macroeconometric Analysis of Growth, Unemployment and Poverty in Nigeria", Pakistan Economic and Social Review, Vol. 43, No. 2 pp. 249-269, University of the Punjab.

21. Priyarsono, D. S. (2011. ), From Agriculture to Industry-Development Analysis from Regional Economic Perspective, Bogor: IPB Press.

22. Sen, Amartya. (1999), Development As Freedom, New York: Anchor Book.

23. Suryadarma, D., Rima Prama Artha, Asep Suryahadi, Sudarno Sumarto. (2005), A Reassessment of Inequality and its Role in Poverty Reduction in Indonesia. SMERU Research Institute.

24. Todaro Michael P. dan Stephen C. Smith. 2011. Pembangunan Ekonomi. Edisi Kesebelas. Jakarta: Penerbit Erlangga.

25. Wahyuni, H. (2004), "Is There A Link between Increased Growth and Reduced Income Inequality? Analysis of Cross-Country Studies", Jurnal Ekonomi dan Pendidikan, Vol. 1, No.1. 